\title{
Interobserver variation in classifying lymphomas among hematopathologists
}

Tawatchai Pongpruttipan', Sanya Sukpanichnant ${ }^{1}$, Thamathorn Assanasen², Lertlakana Bhoopat ${ }^{3}$, Kanita Kayasut ${ }^{4}$, Wasana Kanoksil ${ }^{5}$ and Pongsak Wannakrairot ${ }^{2^{*}}$

\begin{abstract}
Background: Lymphomas are common malignancies that have various subtypes with many overlapping histologic, immunophenotypic and genetic features. Therefore, discordance in classifying lymphoma among pathologists may be encountered. But this issue is not well characterized. We conducted the present study to demonstrate discordances among Thai hematopathologists as well as to highlight common arguing points for classifying lymphomas.
\end{abstract}

Methods: The 117 lymphoma cases were randomly retrieved and individually reviewed by 7 hematopathologists, members of the "Thai Hematopathologist Group," without knowing the original diagnoses. The consensus diagnoses were given from a discussion by all members. In each case, the diagnosis from each participant was compared with the consensus diagnosis and classified into 4 categories as follow: 1) concordance, 2) minor discordance, 3) major discordance and 4) serious discordance.

Results: There were approximately $11 \%$ discordances between original and consensus diagnoses. The average discordances among all pathologists according to minor, major and serious discordances were $10 \%, 3.5 \%$ and $0.3 \%$, respectively. Diffuse large B-cell lymphoma had the least discordance (7\%). Small biopsies had been found to increase discordances in some lymphoma subtypes.

Conclusions: The present study reveals some degrees of interobserver variation in classifying of lymphoma by using the 2008 WHO classification among hematopathologists. Some types of lymphomas on small biopsies were found to have a significant higher discordance rate. This study also described some common diagnostic discordances regarded as potential pitfalls in classifying lymphomas.

Virtual Slides: The virtual slide(s) for this article can be found here: http://www.diagnosticpathology.diagnomx.eu/ vs/13000_2014_162

Keywords: Discordance, Disagreement, Interobserver variation, Pitfall, Hematopathologist, Lymphoma, WHO classification

\section{Background}

Lymphomas are common malignancies worldwide. Due to the advances in immunology and genetic technologies, classification of lymphoma has been regularly updated [1,2]. In the current WHO classification published in 2008, clinical features, histopathology, immunophenotype and genetic features are important to classify lymphomas [1,2]. Since, there were $>30$ lymphoma subtypes in

\footnotetext{
* Correspondence: pongsak.w@chula.ac.th

2Department of Pathology, Faculty of Medicine, Chulalongkorn University, Bangkok, Thailand

Full list of author information is available at the end of the article
}

the 2001 version and $>60$ in the 2008 version. Such many entities have increased the overlapping clinicopathologic features thus may increase difficulty in classifying lymphomas. As previously reported, approximately $10 \%$ of T-cell lymphomas were either misdiagnosed or inadequately subclassified by world expert hematopathologists [3].

Interobserver variation as well as pitfalls in classifying all lymphoma subtypes according to the WHO classification among hematopathologists has not been well documented. We hereby conducted this study to address this issue by allowing 7 Thai hematopathologists, members of the "Thai Hematopathologist Group", to individually 
review 117 lymphoma cases in order to determine the variation in classifying lymphomas. The results of the present study may be useful for hematologists and hematopathologists alike to aware common diagnostic pitfalls.

\section{Methods}

This study was approved by Institutional Review Board of each institution participating in the study, including Faculty of Medicine Siriraj Hospital, Mahidol University, Faculty of Medicine, Chulalongkorn University, Faculty of Medicine, Chiang Mai University, and Faculty of Medicine, Prince of Songkhla University.

The studied cases were recruited from cases with original diagnoses of Hodgkin and non-Hodgkin lymphomas. Mycosis fungoides was excluded from the study. A hundred and nineteen cases were randomly recruited from 4 institutions, but 2 cases were excluded due to inadequate material, thus 117 remained (58 from Chulalongkorn Hospital, 48 from Siriraj Hospital, 8 from Songkhla University Hospital, and another 8 Chiang Mai University Hospital). The cases were selected consecutively, regardless of lymphoma subtypes. Each case was originally diagnosed by either general pathologists or hematopathologists of each institute. All the original diagnoses were made mainly based on evaluation of Hematoxylin and Eosin (H\&E) in conjunction with immunohistochemistry (IHC) slides. Some cases also had additional studies, such as EBV-encoded small RNA (EBER) in situ hybridization, kappa and lambda immunoglobulin light chain in situ hybridization, T-cell receptor gene and/or immunoglobulin heavy chain gene rearrangement analysis.

There were 7 hematopathologists, members of the "Thai Hematopathologist Group", participating to review the cases. We set up two days for meeting. On the first day, there was a 6-hour period for each participant to individually review all 117 cases that provided only $\mathrm{H} \& \mathrm{E}, \mathrm{IHC}$ and in situ hybridization slides. All of clinical data, original diagnoses and pathological reports were not given. Skipping cases without giving diagnosis was not permitted. On the second day of meeting, discussion and consensus on cases with discordance were conducted by all hematopathologists, using microscope with real-time video projector. Each diagnosis given by participants was categorized into 4 categories toward its consensus diagnosis (Table 1). Difficult cases were defined as cases with $\geq 40 \%$ of discordance among participating hematopathologists. Of the 117 cases, 4 were initially unable to make the consensus. After the meeting, additional immunohistochemical staining with or without EBER in situ hybridization were performed and the consensus diagnoses were reached.
Kappa statistics of the five most common lymphoma subtypes of each pathologist was also analyzed.

\section{Results}

Within a 6-hours period given, hematopathologists had variably speeds in reviewing slides, ranged from 56-117 cases (Table 2). All consensus diagnoses were lymphomas. In detail, for the 4 cases that consensus diagnoses were not reached initially, 2 were diffuse large B-cell lymphoma (DLBCL) which required additional IHC for distinguishing from Burkitt lymphoma (BL), while other 2 were extranodal NK/T-cell lymphoma, nasal type (ENKTL) which required additional IHC and EBER in situ hybridization for diagnostic confirmation.

When compared to the consensus diagnoses, each participant had a similar percentage of concordances, ranging from $84-92 \%$ with $86 \%$ in average (Table 2 ). The average frequencies of minor, major, and serious discordances were $10 \%, 3.5 \%$ and $0.3 \%$, respectively (Table 2). Frequencies of each lymphoma subtype and their frequencies of discordances were shown in Table 3.

Five most common lymphomas in the present study were DLBCL, follicular lymphoma (FL), extranodal marginal zone lymphoma of mucosa-associated lymphoid tissue (MALT lymphoma), nodular sclerosis classical Hodgkin lymphoma (NSCHL), and ENKTL. For DLBCL, about half of the discordances were BL while one-third was FL. For MALT lymphoma, 7/8 of discordances were various small B-cell lymphoma subtypes, while the other was "DLBCL versus FL". For FL, 5/9 of discordances were associated with other small B-cell lymphoma subtypes, particularly with nodal marginal zone B-cell lymphoma (NMZL), while $4 / 9$ were debated with DLBCL or with accompanying DLBCL. In addition, 3 out of 7 FLs were small incisional biopsies which had significantly higher discordances when compared to the excisional cases $(7 / 9$ vs. $2 / 19, \mathrm{p}=0.02)$. For NSCHL, all discordances were debated on its various subtypes.

The difficult cases, defined by using the aforementioned criteria, accounted for 16\% (19/117) of all cases were demonstrated in details in Table 4. Of interest, these difficult cases accounted for $71 \%$ of all discordances made.

Compared to the consensus diagnoses, $6 \%$ (7/117) of original diagnoses were with minor discordance and 5\% (6/117) with major discordance (Table 3). No original diagnosis with serious discordance was found. Among the 13 cases with discordant original diagnoses, 11 of them (85\%) also had high discordant rate, fulfilling the criteria of "difficult cases".

In the present study, cases with "serious discordance" were rare. One out of 2 was a NMZL that was misdiagnosed as lymph node with marginal zone hyperplasia by 
Table 1 Definition of each diagnostic category made by hematopathologists when compared to the consensus diagnosis

\begin{tabular}{ll}
\hline Category & Description \\
\hline $\begin{array}{ll}\text { 1. Concordance } & \text { Hematopathologist made a single diagnosis, identical to the consensus diagnosis } \\
& \text { Hematopathologist made }>1 \text { diagnoses, and one of the given differential diagnoses met the consensus diagnosis; } \\
\text { or discordance between classical Hodgkin lymphoma subtypes }\end{array}$ \\
$\begin{array}{ll}\text { 3. Major discordance } & \text { Hematopathologist made } \geq 1 \text { diagnosis(es) of lymphoma, but not any of given diagnosis met the consensus diagnosis } \\
\text { 4. Serious discordance } & \text { Hematopathologist made a diagnosis of reactive process, disagreed to the consensus diagnosis of lymphoma }\end{array}$ \\
\hline
\end{tabular}

one participant. Another was a case of peripheral T-cell lymphoma, not otherwise specified (PTCL, NOS) that was misdiagnosed as atypical lymphoid hyperplasia.

The kappa statistics of the five most common lymphoma subtypes for each pathologist were shown in Table 5. The overall kappa statistics for DLBCL, FL, MALT lymphoma, NSCHL and ENKTL were 0.90, 0.80, $0.84,0.75$ and 0.74 , respectively.

\section{Discussion}

Similar to the present study, other studies also reported a common interobserver variation in classifying lymphomas using other classifications or by various ways [4-7]. The overlapping features among lymphoma subtypes together with either interobserver or interinstitutional variation inevitably lead to discordance [8-10]. In the current WHO classification (2008), many subtypes of lymphomas use mostly the same criteria as those described in the 2001 version, while some underwent critical changes (such as grade $3 \mathrm{FL}$ ). Certainly, some new entities were introduced to the current 2008 version. Generally, effort to classify into more subtypes with detail in criteria should reduce discordant diagnoses. Nevertheless, in practical, discordance in diagnosis still exists and may be due to the frequent overlapping features in many subtypes. A recent study showed an evidence of decreased discordant rate. The authors hypothesized that this may be due to more experience of the pathologists in applying the WHO classification [11].
Distribution of each lymphoma subtype in the present study was similar to the previous study of Thai lymphomas [12]. This suggests a relatively well random selection of cases. There were some limitations on the present study as follow: 1) Only a 6-hours period might remarkably limits participants to diagnose 117 cases very carefully, although they were not forced to review all persisting cases; 2) Lacking of giving clinical information might diminish accurate diagnosis in some cases; 3 ) All participants knew that all recruited cases were originally diagnosed lymphoma, hence less chance for making diagnosis of reactive process; and 4) No results of ancillary studies were provided to the participants.

The present study gave all available slides to the participants, so it is somewhat similar to a process in reviewing pathological diagnosis, except for lacking of provided original diagnosis, clinical information and other ancillary studies. However, the aim of the present study is mainly concentrated to the interobserver variation among hematopathologists. As shown in the results, discordances between the original diagnosis and consensus diagnosis were slightly less than the average of those made by participants, which may be due to the aforementioned limitations.

From each participant, overall discordance of any categories ranged from $8-16 \%$. Almost all were minor and major discordances. The summation of these 2 categories was relatively similar among participants. However, it is not obviously related to the participants' reviewing speeds. These may reflect the personal confidence in

Table 2 Number of reviewed cases and percentage in each diagnostic category of each hematopathologist

\begin{tabular}{|c|c|c|c|c|c|c|c|c|}
\hline & \multicolumn{7}{|c|}{ Hematopathologist $^{\mathrm{a}}$} & \multirow[t]{2}{*}{ Average } \\
\hline & A & B & $\mathrm{C}$ & D & $E$ & $\mathbf{F}$ & $\bar{G}$ & \\
\hline Numbers of reviewed cases ${ }^{b}$ & 117 & 105 & 56 & 94 & 88 & 114 & 81 & $94(80 \%)$ \\
\hline \multicolumn{9}{|l|}{ Category of diagnoses ${ }^{c}(\%)$} \\
\hline 1. Concordance & 84 & 84 & 86 & 92 & 90 & 84 & 85 & 86 \\
\hline 2. Minor discordance & 13 & 12 & 9 & 6 & 7 & 14 & 6 & 10 \\
\hline 3. Major discordance & 3 & 4 & 5 & 2 & 3 & 1 & 7 & 3.5 \\
\hline 4. Serious discordance & 0 & 0 & 0 & 0 & 0 & 1 & 1 & 0.3 \\
\hline
\end{tabular}

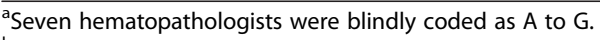

${ }^{b}$ Numbers of reviewed cases are numbers of cases that each hematopathologist could individually review within a 6-hours period

'Please see the description of each diagnostic category in Table 1. 
Table 3 Summary of discordance for each lymphoma subtype made by all hematopathologists

\begin{tabular}{|c|c|c|c|c|c|}
\hline \multirow{2}{*}{ Consensus diagnosis } & \multirow{2}{*}{$\begin{array}{c}\text { Overall } \\
\text { frequency }(\%)\end{array}$} & \multicolumn{4}{|c|}{ Category of diagnoses $^{\mathrm{a}}(\%)$} \\
\hline & & Concordance & Minor discordance & Major discordance & Serious discordance \\
\hline Diffuse large B-cell lymphoma & $68(58)$ & 93 & 4 & 3 & 0 \\
\hline Follicular lymphoma & $7(6)$ & 77 & 20 & 3 & 0 \\
\hline MALT lymphoma & $6(5)$ & 79 & 12 & 9 & 0 \\
\hline Nodular sclerosis classical HL & $6(5)$ & 81 & 19 & 0 & 0 \\
\hline Extranodal NKT-cell lymphoma & $5(4)$ & 65 & 23 & 12 & 0 \\
\hline Nodal marginal zone lymphoma & $3(3)$ & 72 & 16 & 6 & 6 \\
\hline Mixed cellularity classical HL & $3(3)$ & 59 & 41 & 0 & 0 \\
\hline Mantle cell lymphoma & $3(3)$ & 100 & 0 & 0 & 0 \\
\hline Peripheral T-cell lymphoma, NOS & $3(3)$ & 75 & 13 & 6 & 6 \\
\hline Angioimmunoblastic T-cell lymphoma & $2(2)$ & 90 & 10 & 0 & 0 \\
\hline Anaplastic large cell lymphoma & $2(2)$ & 91 & 0 & 9 & 0 \\
\hline T lymphoblastic lymphoma & $2(2)$ & 78 & 22 & 0 & 0 \\
\hline Lymphoplasmacytic lymphoma & $2(2)$ & 18 & 55 & 27 & 0 \\
\hline Classical HL & $1(1)$ & 100 & 0 & 0 & 0 \\
\hline Lymphocyte-rich classical HL & $1(1)$ & 33 & 67 & 0 & 0 \\
\hline Marginal zone/lymphoplasmacytic lymphoma ${ }^{b}$ & $1(1)$ & 100 & 0 & 0 & 0 \\
\hline Subcutaneous panniculitis-like T-cell lymphoma & $1(1)$ & 100 & 0 & 0 & 0 \\
\hline Cutaneous T-cell lymphoma, unclassified & $1(1)$ & 75 & 25 & 0 & 0 \\
\hline Average & & 86 & 10 & 3.5 & 0.3 \\
\hline
\end{tabular}

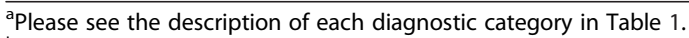

${ }^{\mathrm{b}} \mathrm{A}$ CD5-/CD10-/cyclin D1- small B-cell neoplasm with plasmacytic differentiation in a bone marrow biopsy which definite subtype could not be classified.

making diagnoses, whether some participants preferred to make the most likely single diagnosis or some preferred to include multiple differential diagnoses. A recent study that used WHO classification showed 9\% discordant rate, lower than the present study. This may be caused by several factors including the aforementioned limitation as well as the methodological differences, for example, the former study grouped all T- and NK-cell lymphomas into a single category [11].

In the present study, only viewpoints upon discordances among the five most lymphoma subtypes was discussed. Among the five most common lymphomas, DLBCL had the highest concordance. Similar results among general pathologists have been documented $[7,13]$. In the present study, cases with discordance between DLBCL and BL may represent the unclassifiable B-cell lymphoma with intermediate features between DLBCL and BL in the 2008 WHO classification (2008) [14]. Grade 3 FL with any obvious diffuse growth pattern should be classified as DLBCL in the WHO classification [15]; however, some cases in the present study might have vague diffuse areas leading to diagnostic discordance. Fortunately, treatment for grade $3 \mathrm{FL}$ and DLBCL is similar. In grade $3 \mathrm{~b} \mathrm{FL}$, the neoplastic cells may express IRF4/MUM1 but not CD10 [16]. Other than CD10 and BCL6, HGAL might be a new sensitive marker for germinal center phenotype [17]. Furthermore, in small biopsies, it is a limitation for complete evaluation of nodular architecture, especially in cases with very large irregular neoplastic nodules. IHC markers will be helpful to highlight large neoplastic cells growing in follicular dendritic meshworks in order to reach the diagnosis of this particular FL.

A relatively high rate of discordance in making diagnosis of MALT lymphoma has been reported [6,7]. In the present study, the discordance was raised because participants mainly included other small B-cell lymphomas for differential diagnoses. Although almost cases generally lack of CD5 expression, a small subset of MALT lymphoma may express CD5 $[18,19]$. This may potentially increase discordance rate. Interestingly, one common pitfall is a misdiagnosis of MALT lymphoma with increased scattered large cells as DLBCL [7], that will be concerned as a significant therapeutic alteration. Only cases with definite confluent sheet of large B-cells should be diagnosed as DLBCL, either de novo or histologic transformed case [20]. And it has been documented that high proliferative index by using Ki67 is useful for distinguishing gastric DLBCL from gastric MALT lymphoma [21].

In the present study, FL cases with small incisional biopsies showed significantly higher discordances than those with excisional biopsies. Therefore, making diagnosis on cases with small incisional biopsy should be 
Table 4 Details of the difficult cases $^{a}$

\begin{tabular}{|c|c|c|c|c|c|c|}
\hline \multirow{2}{*}{ Case no. } & \multirow{2}{*}{ Consensus diagnosis } & \multirow{2}{*}{$\begin{array}{l}\text { Discordance of the } \\
\text { original diagnosis }^{b}\end{array}$} & \multicolumn{4}{|c|}{ Frequency of each diagnostic category ${ }^{c}$} \\
\hline & & & Concordance & Minor discordance & Major discordance & Serious discordance \\
\hline 86 & MALT Iymphoma & Minor & 0 & 2 & 3 & 0 \\
\hline 101 & Extranodal NK/T-cell lymphoma ${ }^{d}$ & Major & 0 & 1 & 3 & 0 \\
\hline 19 & Diffuse large B-cell lymphoma ${ }^{d}$ & - & 4 & 0 & 3 & 0 \\
\hline 83 & Lymphoplasmacytic lymphoma & Minor & 0 & 2 & 2 & 0 \\
\hline 32 & Diffuse large B-cell lymphoma & - & 3 & 0 & 2 & 0 \\
\hline 82 & Lymphoplasmacytic lymphoma & Minor & 2 & 4 & 1 & 0 \\
\hline 113 & Peripheral T-cell lymphoma, NOS & Major & 1 & 2 & 1 & 0 \\
\hline 78 & Follicular lymphoma & - & 3 & 2 & 1 & 0 \\
\hline 36 & Diffuse large B-cell lymphoma & - & 0 & 5 & 0 & 0 \\
\hline 100 & Extranodal NK/T-cell lymphoma ${ }^{d}$ & Minor & 0 & 5 & 0 & 0 \\
\hline 93 & Mixed cellularity classical HL & Minor & 1 & 5 & 0 & 0 \\
\hline 76 & Follicular lymphoma & - & 3 & 4 & 0 & 0 \\
\hline 109 & Nodular sclerosis classical HL & Major & 3 & 4 & 0 & 0 \\
\hline 98 & Nodal marginal zone lymphoma & - & 3 & 3 & 0 & 0 \\
\hline 84 & Lymphocyte-rich classical HL & Minor & 1 & 2 & 0 & 0 \\
\hline 91 & Mixed cellularity classical HL & Minor & 3 & 2 & 0 & 0 \\
\hline 62 & Diffuse large B-cell lymphoma ${ }^{d}$ & - & 3 & 2 & 0 & 0 \\
\hline 116 & T lymphoblastic lymphoma & - & 3 & 2 & 0 & 0 \\
\hline 23 & Diffuse large B-cell lymphoma & - & 1 & 1 & 0 & 0 \\
\hline Total & & & 23 & 30 & 11 & 0 \\
\hline
\end{tabular}

${ }^{a}$ Difficult cases were cases that at least $40 \%$ of hematopathologists (participants) made discordant diagnoses.

${ }^{b}$ Original diagnoses, initially made by attending pathologists in clinical services, were also categorized into 4 categories by comparing to the consensus diagnoses. Blanks represent "concordance".

"Please see the description of each diagnostic category in Table 1.

${ }^{d}$ Cases that consensus diagnoses could not be reached at the initial meeting and additional investigations were performed before reaching the consensus diagnoses.

more careful. For the low-grade lymphoma cases, the discordances were mostly associated with other small B-cell lymphoma subtypes; while the high-grade FL was mostly debated between DLBCL as mentioned above.

For NSCHL, particularly those with small biopsies, distinctions between its subtypes were difficult and subjective. Although there are common discordances among subtyping of classical Hodgkin lymphoma, management among the subtypes is the same.

Although EBV positivity is characteristic and specific for ENKTL than other T-cell lymphoma subtypes [22,23], the discordance for ENKTL was relatively high in the present study because $2 / 5$ cases (originally reported as PTCL, NOS and PTCL, NOS versus ENKTL) had no prior EBV studies; so participants included at least 2 differential diagnoses. EBER in situ hybridization was subsequently performed following the consensus, and both cases were positive. Study for EBV is essential for ENKTL, since ENKTL is common NK- and T-cell lymphomas in many Asian countries including Thailand $[24,25]$. Furthermore, ENKTL may be of either $\alpha \beta$ or $\gamma \delta$ T-cell lineage [26], and requires different chemotherapy regimens [27-29], as well as benefits from radiation plus therapy $[26,27]$. Thus, evidence of EBV association by using

Table 5 Kappa statistics of the five most common lymphoma subtypes of each hematopathologist

\begin{tabular}{|c|c|c|c|c|c|c|c|c|}
\hline & \multicolumn{7}{|c|}{ Kappa statistics of each hematopathologist (n) } & \multirow{2}{*}{ Average } \\
\hline & A & B & C & D & $\mathbf{E}$ & $\mathbf{F}$ & G & \\
\hline Diffuse large B-cell lymphoma & $0.93(68)$ & $0.88(60)$ & $0.85(38)$ & $0.96(57)$ & $0.95(47)$ & $0.93(66)$ & $0.92(50)$ & 0.92 \\
\hline Follicular lymphoma & $0.82(7)$ & $0.75(6)$ & $0.45(3)$ & $0.88(5)$ & $0.92(7)$ & $0.82(7)$ & $0.79(5)$ & 0.80 \\
\hline MALT Iymphoma & $0.90(6)$ & $0.65(6)$ & $0.79(3)$ & $0.90(6)$ & $1.00(4)$ & $0.90(6)$ & $1.00(2)$ & 0.84 \\
\hline Nodular sclerosis classical HL & $0.90(6)$ & $0.90(6)$ & $0(1)$ & $0.90(6)$ & $0.92(6)$ & $0.65(6)$ & $1.00(2)$ & 0.75 \\
\hline Extranodal NK/T-cell lymphoma & $0.74(5)$ & $0.85(4)$ & $1.00(3)$ & $1.00(3)$ & $0.49(3)$ & $0.74(5)$ & $0.49(1)$ & 0.74 \\
\hline
\end{tabular}


EBER in situ hybridization is recommended for all CD3positive mature lymphomas. EBV LMP1 and LMP2 immunohistochemistry is positive in some proportion of cases [30], but is not a sensitive test.

Lymphoplasmacytic lymphoma, when without available clinical correlation, was one of lymphomas with a very high discordance rate as shown in this study. This may be due to the lack of specific morphologic and immunophenotypic features but with many overlapping features with other small B-cell neoplasms with plasmacytic differentiation, particularly marginal zone lymphomas with plasmacytic differentiation. Characteristic cytogenetic findings of marginal zone lymphoma, if present, might be a useful feature for dissolving of this issue.

\section{Conclusion}

There are some degrees of interobserver variation in classifying of lymphoma by using the 2008 WHO classification. The uncommon discordances showed in the present study are similar to the previously published studies. The overlapping in morphologic, immunophenotypic and genetic features among various lymphoma subtypes may cause uncommon discordances in classifying lymphomas. Awareness of the overlapping features as well as the common pitfalls might be helpful for reducing discordances among pathologists and hematologists. Some lymphoma subtypes on small biopsies were found to have a significant higher discordance rate, particularly for those which needs architectural evaluation.

\section{Consent}

Written informed consent was obtained from the patient for the publication of this report and any accompanying images.

\section{Abbreviations \\ BL: Burkitt lymphoma; DLBCL: Diffuse large B-cell lymphoma; EBER: EBV-encoded RNA; FL: Follicular lymphoma; H\&E: Hematoxylin and Eosin; IHC: Immunohistochemistry; MALT Iymphoma: Extranodal marginal zone lymphoma of mucosa-associated lymphoid tissue; ENKTL: Extranodal NKTT-cell lymphoma, nasal type; NMZL: Nodal marginal zone B-cell lymphoma; NSCHL: Nodular sclerosis classical Hodgkin lymphoma; PTCL: NOS, Peripheral T-cell lymphoma, not otherwise specified.}

\section{Competing interests}

The authors declare that they have no competing interests.

\section{Authors' contributions}

PW, TP and SS designed the study. All authors reviewed H\&E and IHC slides, as well as conducted the consensus. TP gathered additional information and performed the statistical analysis and wrote the manuscript. All authors read and approved the final manuscript.

\section{Authors' information}

The experience of each pathologist was shown as following. Tawatchai Pongpruttipan: Thai Board of Anatomical Pathology (2006), observer (Division of Hematopathology, University of Pittsburgh School of Medicine, USA, 2010-2011), and hematopathologist at Faculty of Medicine Siriraj Hospital, Mahidol University (2011-present). Sanya Sukpanichnant: Thai Board of
Anatomical Pathology (1989), research fellow (Division of Hematopathology, Vanderbilt University, USA, 1990-1993), and hematopathologist at Faculty of Medicine Siriraj Hospital, Mahidol University (1993-present). Thamathorn Assanasen: Thai Board of Anatomical Pathology (1999), research fellow (Molecular pathology, University of Wurzburg, Germany, 2002-2003), and hematopathologist at Faculty of Medicine, Chulalongkorn University (2004-present). Lertlakana Bhoopat: Thai Board of Internal Medicine (1981), research fellow (Immunopathology and Hematopathology, LAC-USC Medical Center, USA, 1984-1986), Thai Board of Anatomical Pathology (1992), and hematopathologist at Faculty of Medicine, Chiang Mai University (1992-present). Kanita Kayasut: Thai Board of Anatomical Pathology (2001), research fellow (Hematopathology, HOTEL DIEU, Paris, France, 2004-2005), and hematopathologist at Faculty of Medicine, Prince of Songkhla University (2005-present). Wasana Kanoksil: Thai Board of Anatomical Pathology (1999), general pathologist (Khonkaen Hospital, Thailand, 1999-2003), and hematopathologist at Faculty of Medicine Ramathibodi Hospital, Mahidol University (2003-present). Pongsak Wannakrairot: Thai Board of Anatomical Pathology (1983), research fellow (Immunopathology, Institute of Medical and Veterinary Science, 1989), and hematopathologist at Faculty of Medicine, Chulalongkorn University (1990-present).

\section{Acknowledgement}

The authors acknowledge Dr. Chulaluk Komoltri, a statistician of Department of Research Development of Faculty of Medicine Siriraj Hospital, for the analysis of kappa statistics.

\section{Author details}

${ }^{1}$ Department of Pathology, Faculty of Medicine Siriraj Hospital, Mahidol University, 10330 Bangkok, Thailand. 'Department of Pathology, Faculty of Medicine, Chulalongkorn University, Bangkok, Thailand. ${ }^{3}$ Department of Pathology, Faculty of Medicine, Chiang Mai University, Bangkok, Thailand. ${ }^{4}$ Department of Pathology, Faculty of Medicine, Prince of Songkla University, Bangkok, Thailand. ${ }^{5}$ Department of Pathology, Faculty of Medicine Ramathibodi Hospital, Mahidol University, Bangkok, Thailand.

Received: 25 May 2014 Accepted: 9 August 2014

Published: 22 August 2014

\section{References}

1. Jaffe ES, Harris NL, Stien H, Vardiman JW: World Health Organization Classification of Tumours. Pathology and Genetics of Tumours of Haematopoietic and Lymphoid Tissues. Lyon, France: IARC Press; 2001.

2. Swerdlow SH, Campo E, Harris NL, Jaffe ES, Pileri SA, Stein H, Thiele J, Vardiman JW: World Health Organization Classification of Tumours. Pathology and Genetics of Tumours of Haematopoietic and Lymphoid Tissues. Lyon, France: IARC Press; 2008.

3. Armitage J, Vose J, Weisenburger D: International peripheral T-cell and natural killer/T-cell lymphoma study: pathology findings and clinical outcomes. J Clin Oncol 2008, 26:4124-4130.

4. Sheibani K, Nathwani BN, Swartz WG, Ben-Ezra J, Brownell MD, Burke JS, Kennedy $J$, Koo CH, Winberg CD: Variability in interpretation of immunohistologic findings in lymphoproliferative disorders by hematopathologists. A comprehensive statistical analysis of interobserver performance. Cancer 1988, 62:657-664.

5. Santucci M, Biggeri A, Feller AC, Burg G: Accuracy, concordance, and reproducibility of histologic diagnosis in cutaneous T-cell lymphoma: an EORTC Cutaneous Lymphoma Project Group Study. European Organization for Research and Treatment of Cancer. Arch Dermatol 2000, 136:497-502.

6. El-Zimaity HM, Wotherspoon A, De Jong D: Interobserver variation in the histopathological assessment of MALT/MALT lymphoma: towards a consensus. Blood Cells Mol Dis 2005, 34:6-16.

7. Pongpruttipan T, Sitthinamsuwan P, Rungkaew P, Ruangchira-urai R, Vongjirad A, Sukpanichnant S: Pitfalls in classifying lymphomas. J Med Assoc Thail 2007, 90:1129-1136

8. Borlot VF, Biasoli I, Schaffel R, Azambuja D, Milito C, Luiz RR, Scheliga A Spector N, Morais JC: Evaluation of intra- and interobserver agreement and its clinical significance for scoring bcl-2 immunohistochemical expression in diffuse large B-cell lymphoma. Pathol Int 2008, 58:596-600.

9. Kluin-Nelemans JC, Van Wering ER, Van TVMB, Van der Schoot CE, Adriaansen HJ, Van der Burgh FJ, Gratama JW: Pitfalls in the 
immunophenotyping of leukaemia and leukaemic lymphomas: survey of 9 years of quality control in The Netherlands. Dutch Cooperative Study Group on Immunophenotyping of Haematological Malignancies (SIHON). Br J Haematol 1996, 95:692-699.

10. Zu Y, Steinberg SM, Campo E, Hans CP, Weisenburger DD, Braziel RM, Delabie J, Gascoyne RD, Muller-Hermlink K, Pittaluga S, Raffeld M, Chan WC, Jaffe ES: Validation of tissue microarray immunohistochemistry staining and interpretation in diffuse large B-cell lymphoma. Leuk Lymphoma 2005, 46:693-701.

11. Strobbe L, van der Schans SA, Heijker S, Meijer JW, Mattijssen EJ, Mandigers CM, De Kievit IM, Raemaekers JM, Hebeda KM, Van Krieken JH: Evaluation of a panel of expert pathologists: review of the diagnosis and histological classification of Hodgkin and non-Hodgkin lymphomas in a population-based cancer registry. Leuk Lymphoma 2014, 55:1018-1022.

12. Sukpanichnant S: Analysis of 1983 cases of malignant lymphoma in Thailand according to the World Health Organization classification. Hum Pathol 2004, 35:224-230.

13. LaCasce AS, Kho ME, Friedberg JW, Niland JC, Abel GA, Rodriguez MA, Czuczman MS, Millenson MM, Zelenetz AD, Weeks JC: Comparison of referring and final pathology for patients with non-Hodgkin's lymphoma in the National Comprehensive Cancer Network. J Clin Oncol 2008, 26:5107-5112.

14. Kluin PM, Harris NL, Stein H, Leoncini L, Raphael M, Campo E, Jaffe ES: B-cell lymphoma, unclassifiable, with features intermediate between diffuse large B-cell lymphoma and Burkitt lymphoma. In World Health Organization Classification of Tumours Pathology and Genetics of Tumours of Haematopoietic and Lymphoid Tissues. Edited by Swerdlow SH, Campo E, Harris NL, Jaffe ES, Pileri SA, Stein H, Thiele J, Vardiman JW. Lyon, France: IARC Press; 2008:265-266.

15. Harris NL, Swerdlow HS, Jaffe ES, Ott G, Nathwani BN, De Jong D, Yoshino T, Spagnolo D: Follicular lymphoma. In World Health Organization Classification of Tumours Pathology and Genetics of Tumours of Haematopoietic and Lymphoid Tissues. Edited by Swerdlow HS, Campo E, Harris NL, Jaffe ES, Pileri SA, Stien H, Thiele J, Vardiman JW. Lyon, France: IARC Press; 2008:220-226.

16. Jaffe ES: Follicular lymphomas: a tapestry of common and contrasting threads. Haematologica 2013, 98:1163-1165.

17. Goteri G, Lucarini G, Zizzi A, Costagliola A, Giantomassi F, Stramazzotti D, Rubini C, Leoni P: Comparison of germinal center markers CD10, BCL6 and human germinal center-associated lymphoma (HGAL) in follicular lymphomas. Diagn Pathol 2011, 6:97.

18. Terada T: CD5-positive marginal zone B-cell lymphoma of the mucosaassociated lymphoid tissue (MALT) of the lung. Diagn Pathol 2012, 7:16.

19. Jaso JM, Yin CC, Wang SA, Miranda RN, Jabcuga CE, Chen L, Medeiros LJ: Clinicopathologic features of CD5-positive nodal marginal zone lymphoma. Am J Clin Pathol 2013, 140:693-700.

20. Isaacson PG, Chott A, Nakamura S, Muller-Hermelink HK, Harris NL, Swerdlow SH: Extranodal marginal zone lymphoma of mucosa-associated lymphoid tissue (MALT lymphoma). In World Health Organization Classification of Tumours Pathology and Genetics of Tumours of Haematopoietic and Lymphoid Tissues. Edited by Swerdlow SH, Campo E, Harris NL, Jaffe ES, Pileri SA, Stein H, Thiele J, Vardiman JW. Lyon, France: IARC Press; 2008:214-217.

21. Warrick J, Luo J, Robirds D, Branson J, Frater JL, Kreisel F, Hassan A, Nguyen $\Pi$ : Gastrointestinal lymphomas in a North American population: clinicopathologic features from one major Central-Midwestern United States tertiary care medical center. Diagn Pathol 2012, 7:76.

22. Chan JKC, Quintanilla-Martinez L, Ferry JA, Peh S-C: Extranodal NK/T-cell lymphoma, nasal type. In World Health Organization Classification of Tumours Pathology and Genetics of Tumours of Haematopoietic and Lymphoid Tissues. Edited by Swerdlow SH, Campo E, Harris NL, Jaffe ES, Pileri SA, Stein H, Thiele J, Vardiman JW. Lyon, France: IARC Press; 2008:285-288.

23. Pongpruttipan T, Kummalue T, Bedavanija A, Khuhapinant A, Ohshima K, Arakawa F, Niino D, Sukpanichnant S: Aberrant antigenic expression in extranodal NK/T-cell lymphoma: a multi-parameter study from Thailand. Diagn Pathol 2011, 6:79.

24. Au WY, Weisenburger DD, Intragumtornchai T, Nakamura S, Kim WS, Sng I, Vose J, Armitage JO, Liang R: Clinical differences between nasal and extranasal natural killer/T-cell lymphoma: a study of 136 cases from the International Peripheral T-Cell Lymphoma Project. Blood 2009, 113:3931-3937.
25. Pongpruttipan T, Pongtongcharoen P, Sukpanichnant S: Mature T-cell and NK-cell lymphomas in Thailand: an analysis of 71 cases. J Med Assoc Thail 2011, 94:743-748,

26. Pongpruttipan $T$, Sukpanichnant $S$, Assanasen $T$, Wannakrairot $P$, Boonsakan $P$, Kanoksil W, Kayasut K, Mitarnun W, Khuhapinant A, Bunworasate U, Puavilai T, Bedavanija A, Garcia-Herrera A, Campo E, Cook JR, Choi J, Swerdlow SH: Extranodal NK/T-cell lymphoma, nasal type, includes cases of natural killer cell and alphabeta, gammadelta, and alphabeta/gammadelta T-cell origin: a comprehensive clinicopathologic and phenotypic study. Am J Surg Pathol 2012, 36:481-499.

27. Kwong YL: The diagnosis and management of extranodal NK/T-cell lymphoma, nasal-type and aggressive NK-cell leukemia. J Clin Exp Hematop 2011, 51:21-28.

28. Jaccard A, Petit B, Girault S, Suarez F, Gressin R, Zini JM, Coiteux V, Larroche C, Devidas A, Thieblemont C, Gaulard P, Marin B, Gachard N, Bordessoule D, Hermine O: L-asparaginase-based treatment of 15 western patients with extranodal NK/T-cell lymphoma and leukemia and a review of the literature. Ann Oncol 2009, 20:110-116.

29. Suzuki R: Treatment of advanced extranodal NK/T cell lymphoma, nasal-type and aggressive NK-cell leukemia. Int J Hematol 2010, 92:697-701.

30. Mao Y, Zhang DW, Zhu H, Lin H, Xiong L, Cao Q, Liu Y, Li QD, Xu JR, Xu LF, Chen RJ: LMP1 and LMP2A are potential prognostic markers of extranodal NK/T-cell lymphoma, nasal type (ENKTL). Diagn Pathol 2012, 7:178.

\section{doi:10.1186/s13000-014-0162-3}

Cite this article as: Pongpruttipan et al:: Interobserver variation in classifying lymphomas among hematopathologists. Diagnostic Pathology 2014 9:162

\section{Submit your next manuscript to BioMed Central and take full advantage of:}

- Convenient online submission

- Thorough peer review

- No space constraints or color figure charges

- Immediate publication on acceptance

- Inclusion in PubMed, CAS, Scopus and Google Scholar

- Research which is freely available for redistribution 